Provided for non-commercial research and education use. Not for reproduction, distribution or commercial use.

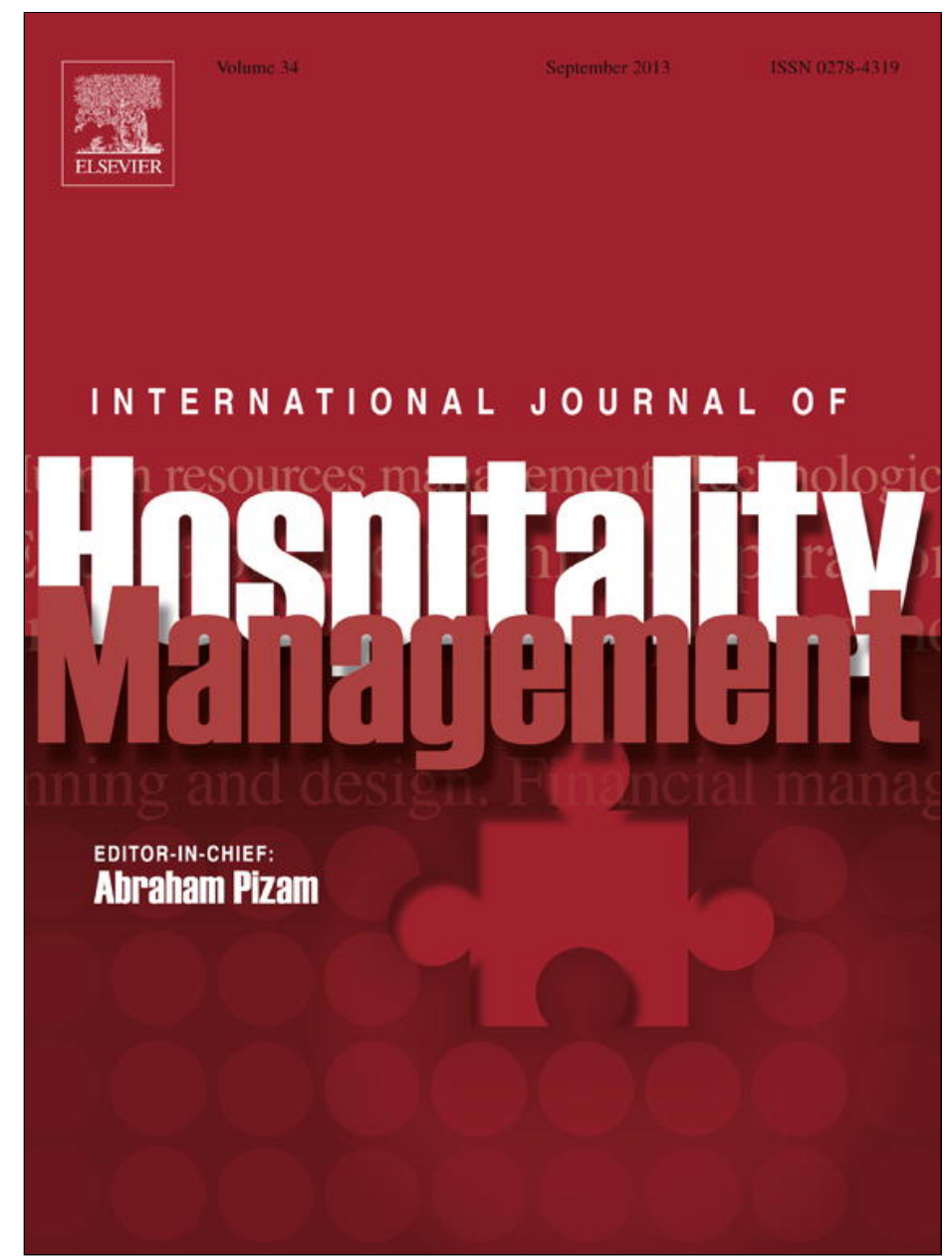

This article appeared in a journal published by Elsevier. The attached copy is furnished to the author for internal non-commercial research and education use, including for instruction at the authors institution and sharing with colleagues.

Other uses, including reproduction and distribution, or selling or licensing copies, or posting to personal, institutional or third party websites are prohibited.

In most cases authors are permitted to post their version of the article (e.g. in Word or Tex form) to their personal website or institutional repository. Authors requiring further information regarding Elsevier's archiving and manuscript policies are encouraged to visit:

http://www.elsevier.com/authorsrights 


\title{
Does risk matter in CEO compensation contracting? Evidence from US restaurant industry
}

\author{
Ozgur Ozdemir ${ }^{\mathrm{a}, *}$, Murat Kizildag ${ }^{\mathrm{b}}$, Arun Upneja ${ }^{\mathrm{c}}$ \\ a School of Applied Sciences, Ozyegin University, Cekmekoy, Istanbul 34794, Turkey \\ ${ }^{\mathrm{b}}$ College of Human Sciences, Texas Tech University, Lubbock, TX 79409, United States \\ c Schreyer Honors College, The Pennsylvania State University, 10 Atherton Hall, University Park, PA 16802, United States
}

\section{A R T I C L E I N F O}

\section{Keywords:}

CEO

Compensation

Firm risk

Restaurant industry

\begin{abstract}
A B S T R A C T
The structure of compensation packages of Chief Executive Officers (CEOs) has been a significant research interest for researchers across various disciplines. In this paper, we examine a unique relationship between CEO compensation and risk (systematic risk) in the US restaurant industry. Our research question stems from the assumption that CEOs must be rewarded with a higher incentive-based compensation in high-risk profile restaurant companies in order to motivate them to perform in their full potential for mutual benefits of the CEO and shareowners. Furthermore, we investigate whether firm risk moderates the relationship between firm performance and CEO total compensation controlling for the firm size and CEO ownership. We draw our sample firms from the US restaurant industry. Findings of our study suggest that firm risk induces a higher proportion of incentive-based compensation for restaurant companies' CEOs, and firm risk does not seem to moderate the relationship between pay and performance in the restaurant industry.
\end{abstract}

(C) 2012 Elsevier Ltd. All rights reserved.

\section{Introduction}

A quick review of the past two decades in finance, accounting, and management literature reveals that there has been a steady increase in the number of studies examining the link between executive compensation and firm performance (Tosi et al., 2000). Perhaps one of the reasons for the rapid increase in the quantity of compensation studies is the economic significance of inflated compensation packages on shareowners' and other stakeholders' wealth. While the purported relationship between compensation and performance is still questionable, the average pay-package of chief executive officers (CEO) of US companies has gone up noticeably. In a recent article (Wall Street Journal, 2011), it was reported that CBS Corporation's CEO, Les Moonves, received compensation for 2010 valued at about $\$ 57.7$ million. This is only one of the examples that represent the enormous compensation packages offered to company executives, and yet it is enough to get the attention of various stakeholders of a company who wonder at the enormity of the compensation packages.

The growing literature on compensation research has its roots in the alleged relationship between firm performance and executive compensation. CEO's compensation, outweighing significantly

\footnotetext{
* Corresponding author.

E-mail address: ozgur.ozdemir@ozyegin.edu.tr (O. Ozdemir).
}

those of their immediate subordinates as well as those of line employees, has been the core of the investigation. Knowing that organizational outcomes are linked to the leadership and managerial talent (Gray and Canella, 1997), it is understandable why the attention has focused on CEO's compensation. This is indeed in line with the normative prescription of agency theory (Gray and Canella, 1997) grounded on the presumption that compensation packages should be closely tied to organizational outcomes from corporate performance. This argument in prior research still constitutes a relevant topic for research and tries to capture the optimal level of ownership and CEO incentive system (i.e. Florackis et al., 2009; Jurkus et al., 2011; Wu and Tu, 2007).

An examination of the previous studies in the compensation literature shows that firm size is by far the most significant determinant of the CEO compensation level while firm performance explains only a small portion of the variation in CEO compensation level (Finkelstein and Hambrick, 1988; Kroll et al., 1990). Further evidence shows that strong governance quality, such as independent boards, accounts for some of the variation in the CEOs' compensation levels as well (Core et al., 1999; Gomez-Mejia et al., 1987; Boyd, 1994). Inconclusive and confusingly contradicting findings have motivated further research in this particular domain of corporate governance. However, one area that has garnered less attention in the compensation literature has been the impact of firm risk on the CEO's compensation structure. Firms with a highrisk profile tend to encounter higher outcome uncertainty, which 
reduces executives' motivations to invest in risky projects. In this regard, one of the challenges firms (owners) encounter is to design compensation packages that are intended to motivate risk-averse agents to bear higher risk in order to undertake value-increasing projects (Murphy, 2000). Hence, pay-premium offered to executives in an effort to increase their risk-taking propensity is one of the important contractual mechanisms to reduce agency costs (Shavell, 1979).

In this study, we examine the role of firm risk on the CEO compensation contracting practices. Specifically, we try to understand whether the structure of the CEOs' compensation changes as the level of risk they have to bear increases. Furthermore, we investigate whether the relationship between pay and performance is influenced by firm risk.

Our study contributes to the previous literature in several ways. First, we estimate the relationship between firm risk and compensation along with the pay-performance relationship and focus on a particular aspect of the compensation-incentive pay. The exact direction of the pay-performance relationship is not crystal-clear (Jensen and Murphy, 1990), which leads to a potential endogeneity problem between pay and performance (Duru and Iyengar, 1999). If not taken care of, untreated simultaneity between pay and performance can lead to fallacious regression specifications and inefficient parameter estimates. In order to account for the potential endogeneity we estimate our regression models in a simultaneous equations modeling framework. Second, we use a sample of firms from the US restaurant industry, which is part of the larger services sector. Several factors encourage us to examine our research question in this particular industry. Restaurant business has traditionally been known as a risky business and the risk varies among the segments of the industry (Kim, 2009). For instance, De Noble and Olsen (1986) discuss that restaurant industry has the highest market volatility among seven industries they have tested. Moreover, Huo and Kwansa (1994) documented that restaurant industry is the riskiest (highest beta) industry group in a study where they compared the betas of hotel, restaurant and utility firms. Moreover, macroeconomic downturns, difficulties in entering long-term fixed-price supply contracts, and the ease with which consumers can give up away-from-home food consumption add to the operational challenges of the restaurant industry (Risk Center, 2009). Earnings and operating margins of the restaurant companies heavily depend on the availability of leisure time and disposable income of consumers. Thus, uncertainty of consumer spending, fluctuating supply and demand quantities, ambiguities in macro factors such as consumer price index (CPI), gross domestic product (GDP) and gross national product (GNP) all add to the risk in the restaurant industry. Furthermore, restaurant firms face a high likelihood of failure from the point of their inception. About 30 percent of the restaurants fail in their first year of operations (Parsa et al., 2005). Lastly, using a single industry provides homogeneous data that avoids contamination of industry specific factors. High risk profile and substantial failure rates make the restaurant industry an appealing candidate to investigate the role of firm risk in the CEOs' compensation structure and to observe how board of directors attempt to align the interests of CEOs with those of the owners. Furthermore, using only restaurant firms provides important insights to restaurant operators and their BODs to draw direct inferences about the firm risk on shaping CEO compensation packages. With all that pointed out, we attempt to contribute to the compensation contracting literature by extending the knowledge of the relationship between risk and compensation. This phenomenon has not been fully understood in the mainstream literature because the sample firms come from industries providing mixed findings. Further, focusing on a particularly risky industry, the current study attempts to pinpoint the role of varying firm risk on the structure of pay-packages of restaurant CEOs. By doing so, the current study aims at providing insightful implications to the practitioners of the hospitality industry as well.

The remainder of the paper is organized as follows. In Section 2 , we provide evidence from previous research. In Section 3, we describe our sample, data, and introduce our empirical methods. Section 4 reports the results. Section 5 presents robustness tests and Section 6 summarizes and concludes.

\section{Review of related literature}

\subsection{Principal-agent theory and pay-performance studies}

An optimal level of executive compensation and firm performance are the inseparable dynamics in a firm's strategy. For instance, an optimal executive pay contract will not only benefit firms' operations but also hedge to exogenous events - e.g. immediate switch in firm's stock options policy (Balsam et al., 2011).

Previous research focused on factors that help explain the variation in CEO compensation and found mixed and inconclusive results. It has been well documented that firm size, firm performance, and corporate governance qualities (including but not limited to board characteristics and ownership structure) are important determinants of CEO compensation (Core et al., 1999; Mehran, 1995).

It has also been shown that boards of directors need to take some initiative to stabilize the conflicting interests of agents and shareholders (Walsh and Seward, 1990) so as to avoid the suboptimal managerial decisions that are detrimental to the firm's value. One of the ways to alleviate the adverse effect of the unmatched interests of two parties is to associate executive pay with firm performance (Canarella and Nourayi, 2008; Murphy, 1985; Glassman and Rhoades, 1980). Thus, principal-agent theory claims that if the CEO's total compensation is tied to his/her performance, it would induce a positive motivation for CEOs to make value-increasing decisions and to achieve operational performance benchmarks. The choice of the performance measure in the literature is quite mixed. Accounting measures (i.e. return on assets (ROA), return on equity (ROE), earnings per share (EPS)) and market measures (i.e. stock returns and Tobin's $Q$ ) are a few that have been used in prior research.

Most of the studies done in the past two decades were aimed at finding the impact of firm performance either on the aggregate CEO compensation or on its particular components. Depending on the distinctiveness of the research question, some studies encompassed other economic, governance, and CEO related attributes into their investigation as well. For instance, Core et al. (1999) examine the determinants of CEO compensation controlling for several firm-specific factors. In their comprehensive study, they not only look at the influence of economic factors (ROA and stock return) on CEO compensation, but further hypothesize that ownership structure and board composition characteristics are also significant contributors to explaining the variation in CEO compensation level (total compensation, cash compensation, and salary). Their results demonstrate that stock returns are statistically significant in explaining the variation in total CEO compensation, but ROA is not. In addition, they find that firm size is positively associated with total CEO compensation, and firms with higher investment opportunities (as proxied by the market-to-book ratio) pay higher CEO compensation. In support of the findings of Core et al. (1999), Madura et al. (1996), and Skalpe (2007) report an insignificant association between CEO compensation, and ROE and ROA. Further studies, on the other hand, show that accounting measures are an important indicator of firm performance. Attaway (2000) and Veliyath and Bishop (1995) find that CEO cash compensation is positively related to return on equity. Similarly, Cooley (1979) 
shows that profitability is positively associated with managerial pay in small businesses when he draws a sample of firms from the petroleum marketers industry. From an international markets perspective, Firth et al. (2007) report a positive association between executive pay and firm performance (ROA) in China. Among several industry-level studies, Crumley (2008) examine the determinants of CEO compensation in the US banking industry and found that stock return is a significant determinant of compensation. Likewise, Veliyath and Bishop (1995) examine the pay-performance relationship in the US drug and pharmaceutical industry and report a positive relationship between CEO cash compensation and ROA.

\subsection{Risk factor in the compensation contracting}

Core et al. (1999) examine the impact of a set of corporate characteristics on the CEO's cash compensation and find that firm risk (standard deviation of return on assets and standard deviation of returns) is negatively related to compensation. Likewise, Bloom and Milkovich (1998) provide a negative link between firm risk and CEO's bonus pay to base salary ratio. When risk is measured in terms of the standard deviation of stock returns, Garen (1994) finds weak evidence for the hypothesis that CEO's stockrelated compensation is decreasing in the standard deviation of firm returns. In the same line, Aggarwal and Samwick (1999) document that CEO's pay-performance sensitivity is decreasing in the variance of their firms' stock returns for various compensation components. Contrarily, a recent study by Haggard and Haggard (2008) revealed that CEO's base salary and total compensation are positively related to the firm risk the CEO has to bear. Mehran (1995), on the other hand, reports that business risk (standard deviation of the percentage change in the operating income) is not related at all to the proportion of CEO's equity-based compensation. As the previous research shows the findings are mixed and inconclusive and, therefore, lend themselves to more research in this field. Researchers from other disciplines look into the effect of various risk proxies on different compensation components. For instance, Wen and Chen (2008) investigate the association between total risk, insurance risk, and idiosyncratic risk and CEO compensation contracts in the property/liability insurance industry and find that firm risk does not increase the proportion of option-based pay over total pay in this industry.

There is only a handful of compensation studies conducted specifically for the hospitality industry, and firm risk has not been the focus of any of these previous studies (Jang and Park, 2011). Among those studies, Barber et al. (2006) investigate the relationship between stock price and CEO compensation in the US restaurant industry. Similarly, Madanoglu and Karadag (2006) look into the effect of firm performance on the change of CEO cash compensation (pay-performance sensitivity). In the same vein, Kim and $\mathrm{Gu}(2005)$ examine the determinants of CEO pay in the US restaurant industry and report that firm size is the major determinant of CEO's total cash compensation. Dalbor et al. (2010) examine the restaurant industry and provide evidence of a market performance effect on the CEO's total compensation. In a more recent study, Guillet et al. (2012) examine the executive compensation in the restaurant industry and report varying results for $\mathrm{CEO}$, senior executive officers and board members. According to their study, firm size and tenure appeared to be common determinants of executive compensation in the restaurant industry.

\section{Econometric model of executive compensation and firm risk}

\subsection{Research hypotheses}

Compensation arrangements vary in the extent to which executives bear risk given the compensation they are paid from year to year. At one extreme, executives with only fixed income bear no compensation risk. In contrast, executives experiencing performance contingent compensation bear large risks with respect to the level of compensation (Gray and Canella, 1997). Miller et al. (2002) argue that the degree of firm risk should assert distinctive effects on executive compensation risk bearing.

The first hypothesis of our study concentrates on the contention that equity-based compensation is tied to market performance of the firm, which requires undertaking riskier projects that are aimed at maximizing shareholder return. This, in turn, exhibits greater risk for the firms and higher uncertainty for the managers to deal with. The board of directors expects managers to work through the exposed uncertainty and risk and maintain their motivation to align their own interests with those of owners. One way of ensuring this is to use higher equity-based compensation to increase the overall wealth of managers and keep them motivated toward achieving financial goals of both parties. Based on this argument, we expect that as the risk of a company increases, board of directors, on behalf of owners, will prefer to pay a higher proportion of equity-based compensation to total compensation to the CEO of the firm. If it turns out to be true, then we should be able to observe a positive coefficient on the risk variable in a regression of incentive-pay (ratio of equity-based compensation to total compensation) on firm risk.

H1. The ratio of CEO's equity-based compensation to total compensation is positively related to firm risk in the US restaurant industry.

To further investigate the impact of firm risk on the overall structure of CEO compensation, we look into how it affects the well-known relationship between compensation and performance. In a traditional compensation package, pay is mainly tied to performance and therefore better performing executives are paid higher compensation (Jensen and Murphy, 1990; Mehran, 1995; Veliyath and Bishop, 1995). Combined with the riskiness proposition, positive effect of performance on the CEO compensation level could be further enhanced. Given that pay is positively affected by performance, increased riskiness can infer a higher compensation package for CEOs in the restaurant industry. In fact, this could be intuitively expected because achieving a unit increase in the company performance would be more challenging for a risky company than a less risky company. Therefore, the return for the CEO, which shows up in higher total compensation, should be more appealing so as to keep them motivated and rewarded. Henceforth, we expect that firm risk may moderate the relationship between pay and performance, and board of directors allocate a higher compensation for a riskier business than a less risky business for the same unit of increase in the company performance. We expect this relationship to hold even within an industry. With that argument, we formulate Hypotheses $2 \mathrm{a}$ and $2 \mathrm{~b}$ for accounting performance and market performance measures.

H2a. Riskier firms pay a higher compensation to their CEOs for a unit increase in the accounting performance of the company, ceteris paribus.

H2b. Riskier firms pay a higher compensation to their CEOs for a unit increase in the market performance of the company, ceteris paribus.

\subsection{Variables}

Beta, as a measure of systematic risk, is the only security-specific parameter that affects the equilibrium return on a risky security (Mandelker and Rhee, 2009). We use market-driven risk in this study and utilize Carhart's four-factor model composed of beta $(\beta)$, size factor (SMB), book-to-market factor (HML) (Fama and French, 1992), and momentum factor (UMD). The beta coefficient provides 
a clear and quantifiable measure of risk and is the most robust risk proxy in assessing an assets' risk class (Fama and French, 1993). Kothari et al. (1995) suggest that the value-weighted stock index is preferred as a market proxy over the equally weighted index. Thus, S\&P 500 is utilized as a benchmark because the components of the index are weighted according to the total market value of their outstanding shares in our beta $(\beta)$ estimation for the firms considered in our sample. Also, 30-day T-bill rate is taken as a proxy for risk-free rate in this computation.

We define compensation in two ways. First, we define a proxy for incentive compensation. It is operationalized as the ratio of equity-based compensation to total compensation. Equity-based compensation is operationalized as the sum of stock options and stock awards (Chhaochharia and Grinstein, 2009). Stock options are Black and Scholes values and stock awards are valued at the grant date fair value. Second, we define total compensation as the sum of salary, bonus, stock awards, stock options, and all other long-term pay components. Consistent with prior research in the compensation literature, we account for the effect of firm performance and firm size as well (Attaway, 2000; Jensen and Murphy, 1990). To control for the performance effect on compensation, we use both an accounting measure and a market measure in our models. In line with previous studies we use return on assets and stock return as the performance proxies. We include firm size variable to control for the possible effect that larger the firm, larger the compensation level (Ke et al., 1999; Anderson et al., 2000).

In addition to the firm specific determinants of CEO compensation, we also account for the CEO's age and CEO's previous stock ownership. There are two competing views regarding the effect of CEO's age on his/her compensation. The first view suggests that as a CEO gets older, his/her horizon with the company diminishes and, therefore, CEOs pursue less risk-inducing projects, which then may result in an incentive for board of directors to keep CEO compensation fixated at a certain level. This would show up in a form of reduced compensation packages for retiring or near retiring age executives. Opposed to this view, a competing view suggests that CEO's age implies tenure, and tenure must be rewarded with a premium (Conyon et al., 2001). Given these opposing views about CEO age, we avoid making any prediction about the sign of this variable but include it to control for the human capital effect on compensation. With regards to CEO ownership, Khan et al. (2005) argue that as CEO's ownership increases, there will be less need for monitoring on CEOs because ownership helps to align owner's and agents incentives. Therefore, we believe that CEOs would strive to perform their best to keep the firm performance at maximum and increase their stake in the firm. Hence, we also control for this ownership effect in our econometric model.

\subsection{Sample and data}

We collect our data from three sources. Compensation data comes from the Compustat's ExecuComp database for years 1992-2009. Company financials are from Compustat annual filings, and stock returns are calculated from the stock prices obtained from monthly stock files in CRSP. For our risk variable (beta) estimation, our sample firms must match the following criteria: (a) have adjusted month-end closing stock prices including capital changes (i.e. stock and cash dividends), and (b) have Compustat data for accounting information. For compensation constructs, we obtained all compensation data from ExecuComp database for SIC code 5812 (Eating Places). The final sample included 47 restaurant companies publicly traded over the period of 1992-2009. We retrieve compensation data from ExecuComp database for 544 CEO firm year observations. These data include CEO's annual salary, bonus and total equity-based compensation. We collect sample firms' financial data from Compustat and CRSP for the observation years of 1992-2009. Further, two databases are merged resulting in a reduced sample size of 240 complete firm year observations. The major source of decline in the sample size is the lack of equity-based compensation data (249 cases). Additional reduction in the sample size is caused by 28 missing observations for growth variable, 17 missing observations for CEO's previous stock ownership variable, 9 missing observations for age variable and 1 missing observation for cash compensation variable.

\subsection{Empirical methodology}

If the managers view the increased firm risk as a potential threat for their future wealth they might be less inclined to take on projects that add to the level of riskiness of a company. In return, bypassing risky projects may reduce the earnings and return potential of a company because risky projects have a higher potential for incremental returns. Taking into account the executives' concerns about their future compensation and return prospects of a company, board of directors need to set compensation schemes that will effectively meet executives' concerns and owners' return prospects. In this study, we propose that board of directors achieve a balance by allocating a higher proportion of equity-based compensation to their CEOs as the level of firm risk CEOs face increases. By doing so, board of directors ensure that CEOs are induced to take on value-increasing risky projects that is in the best interest of owners, and at the same time they are promised to be awarded by the potential future returns of these value-increasing projects. To test for this incentive hypothesis (H1), we estimate the following systems of equations. We opt to test our hypothesis in a simultaneous equation modeling framework mainly because of the endogeneity concerns between the performance and compensation variables.

$$
\begin{aligned}
\text { Inc_Comp }= & \beta_{0}+\beta_{1} \text { Roa }_{t}+\beta_{2} \text { Return }_{t}+\beta_{3} \text { Risk }_{t}+\beta_{4} \text { InSales }_{t} \\
& +\beta_{5} \text { Age }_{t}+\beta_{6} \text { CeoOwn }_{t-1}+\varepsilon
\end{aligned}
$$

Roa $_{t}=\gamma_{0}+\gamma_{1}$ InCashComp $_{t}+\gamma_{2}$ InSales $_{t}+\gamma_{3}$ Leverage $_{t}$

$$
+\gamma_{4} \text { Growth }_{t}+\gamma_{5} \text { CeoOwn }_{t-1}+\varepsilon
$$

Return $_{t}=\alpha_{0}+\alpha_{1}$ InEquityComp $_{t}+\alpha_{2}$ InSales $_{t}+\alpha_{3}$ Leverage $_{t}$

$$
+\alpha_{4} \text { Growth }_{t}+\alpha_{5} \text { CeoOwn }_{t-1}+\varepsilon
$$

Inc_Comp: The ratio of equity-based compensation to total compensation. Equity-based compensation is operationalized as the sum of stock options and stock awards. Total compensation is the sum of equity-based compensation and cash compensation (salary plus bonus).

Roa: Return on assets, operationalized as net income at the end of year $t$ divided by total assets at the end of year $t$.

Return: Stock return, operationalized as the closing stock price in year $t$ minus the closing stock price in year $t-1$, divided by the closing stock price in year $t-1$.

Risk: Systematic risk, beta coefficient Carhart's four-factor model. InSales: Natural logarithm of total sales.

Age: CEO's age at each fiscal year end.

CeoOwn $n_{t-1}$ : CEO initial stock holdings as of the end of last year's fiscal year end.

InCashComp: Natural logarithm of CEO's cash compensation including salary and bonus.

Leverage: Ratio of long-term debt to total assets.

Growth: Sales growth rate defined as the current year's total sales minus last year's total sales divided by the last year's total sales. InEquityComp: Natural logarithm of CEO equity compensation defined as the sum of stock options and stock awards. 
In accordance with our discussion above, we expect that as the level of risk increases, proportion of equity-pay to total-pay increases. Therefore, we expect a positive coefficient on the risk variable in compensation model (Eq. (1)). Furthermore, consistent with prior research (Jensen and Murphy, 1990; Attaway, 2000), we anticipate positive coefficients on the performance measures, Roa and Return, in the compensation model (Eq. (1)). Size was consistently found to be a strong predictor of executive compensation (Core et al., 1999). Therefore, we also expect a positive sign for size variable, which is log of sales, InSales. In addition to performance and size variables, we also control for CEO age and CEO ownership, and expect a positive sign for ownership. We avoid making a prediction for the direction of the age variables for the reasons we discussed in the hypotheses section.

We estimate our systems of equations via three-stage least squares (3-sls). An ordinary least square (OLS) analysis in our setting would jeopardize the unbiasedness of parameter estimates. Wen and Chen (2008) and Iyengar and Zampelli (2008) show that performance and compensation are endogenous and need to be jointly estimated. Otherwise, the parameters from the compensation equation would produce unreliable parameter estimates. Keeping with Wen and Chen (2008) and Iyengar and Zampelli (2008), we attempt to control for endogeneity between firm performance and compensation in our regression models. Both Wen and Chen (2008), and Iyengar and Zampelli (2008) use 2-sls regression as their estimation method. However, an estimation method that accounts for the correlations among the errors terms from each equation of a system of equations would be more appropriate. As Eqs. (1)-(3) depict, we have a series of equations, and endogenous variables from Eqs. (2) and (3) are used as explanatory variables in Eq. (1). Therefore, it is appropriate to estimate our system of equations via 3-sls. 3-sls is a mixed estimation method of 2-sls and SUR (Seemingly Unrelated Regression) and alleviates the endogeneity problem among endogenous variables allowing for the use of endogenous variables as exogenous variables in at least one of the other equations within the system of equations. ${ }^{1}$ Besides, 3 -sls is asymptotically more efficient than 2 -sls. Its asymptotic efficiency arises from exploiting nonzero cross-equation covariation (Belsley, 1988). Whereas the 2 -sls assumes that cross-equation covariation is zero in a system of equations, the 3-sls uses the estimated crossequation covariation in the estimation process.

\subsubsection{Roa equation}

Canarella and Nourayi (2008) mention that accounting-based measures are less relevant from the shareholders' perspective mainly because they are ex-post and historical measures of firm performance. In addition to this drawback, accounting-based measures are usually related to fixed cash component of compensation (Mehran, 1995). This is largely due to the risk-averseness of the managers. That being said, executives offered generous cash compensation (fixed-component) must be motivated to boost accounting-based performance in order to increase their potential fixed compensation in future periods. We, therefore, specify model 2 , which predicts that Roa is related to CEO's cash compensation (fixed component).

\subsubsection{Return equation}

Previous research has shown that investors view stock returns as a more significant input to judge the performance of a firm (Canarella and Nourayi, 2008). They claim that market-based mea-

\footnotetext{
1 SUR would have been an appropriate estimation method however, it does not allow for the use of endogenous regressors as exogenous variables in other equations. However, we have endogenous regressors that are used as exogenous regressors in at least one of the other equations within the system of equations.
}

Table 1

Summary statistics of $\beta$ and Carhart's four-factor model coefficients ( $\beta$, SMB, HML, UMD) between the years 1992 and 2009 .

\begin{tabular}{|c|c|c|c|c|}
\hline \multicolumn{5}{|l|}{ Panel A } \\
\hline$\beta$ coefficient intervals & \multicolumn{3}{|c|}{ \# of firms } & $\%$ \\
\hline$<0.5$ & \multicolumn{2}{|r|}{2} & & 0.04 \\
\hline $0.5-1.00$ & \multicolumn{2}{|r|}{11} & & 0.23 \\
\hline $1.00-1.50$ & \multicolumn{2}{|r|}{7} & & 0.15 \\
\hline $1.50-2.00$ & \multicolumn{2}{|r|}{18} & & 0.38 \\
\hline $2.00-2.50$ & \multicolumn{2}{|r|}{4} & & 0.09 \\
\hline $2.50-3.00$ & \multicolumn{2}{|r|}{3} & & 0.06 \\
\hline$>3.00$ & \multicolumn{2}{|r|}{2} & & 0.04 \\
\hline Firms total & \multicolumn{2}{|r|}{47} & & \\
\hline \multicolumn{5}{|l|}{ Panel B } \\
\hline & $\beta$ & SMB & HML & UMD \\
\hline Overall arithmetic average & 1.62 & 0.56 & 0.73 & 0.28 \\
\hline Median & 1.29 & 0.21 & 0.38 & 0.16 \\
\hline Minimum & 0.20 & -0.26 & 0.10 & -0.19 \\
\hline Maximum & 4.41 & 0.44 & 0.93 & 0.41 \\
\hline Spread & 4.21 & 0.70 & 0.83 & 0.60 \\
\hline
\end{tabular}

Out of total firms (48), NPC International, Inc. is excluded from our beta estimations because NPC went private and was sold to Merrill-Lynch Global Private Equity Group. The reason we applied arithmetic average rather than geometric average for overall average is simply because each coefficient is independent of each other and each coefficient carries absolute values.

sures are ex ante forward-looking measures of performance and therefore, these measures are supposed to mitigate the agency problem between owners and managers. This can be accomplished by the compensation packages that are related to the stock performance of the firms. Under these circumstances, CEOs with large equity-based compensation should strive to increase the stock performance of their firms in order to raise their own wealth. Eventually, increased stock return entails mutual benefits for owners and managers. In line with this argument, several studies have shown that market-based performance measures are related to executive compensation (Murphy, 1985; Coughlan and Schmidt, 1985). Therefore, we form Eq. (3) such that stock return is expected to be related to equity-based compensation.

Mehran (1995) finds that CEO's stock ownership (percentage of shares held by the CEO) is positively related to firm performance (measured as ROA and Tobin's $Q$ ). Hence, we also control for the CEO's previous stock ownership in our performance equations in accord with the finding of Jensen and Meckling (1976) that managers' incentives to work harder and boost performance increase as their ownership in the firm rises. Finally, we include leverage and growth in our performance equations in line with Mehran (1995) and Switzer and Tang (2009).

\subsubsection{Computation of firm risk (systematic risk)}

We derive our risk variable $(\beta)$ by estimating the following fourfactor model (Carhart, 1997):

$$
R_{i t}-R_{f}=\beta_{i}\left(R_{m t}-R_{f}\right)+s_{i} S M B_{t}+h_{i} H M L_{t}+U M D_{t}+\alpha_{i}
$$

In Carhart's four-factor model, $R_{i t}-R_{f}$ is explained by (i) the excess return on a market portfolio $R_{m t}-R_{f}$, (ii) the difference between the return on a portfolio of stocks with a high book-valueto-price ratio (value stocks) and the return on a portfolio of growth stocks (SMB, small minus big); and (iii) the difference between the return on a portfolio of high book-to-market stocks and the return on a portfolio of low book-to-market stocks (HML, high minus low). The last component in this model is the momentum factor (UMD). This factor represents the monthly return differences between the high and low prior return portfolios to enclose crosssectional return performance (Carhart, 1997). 
Table 2

Correlations between four factors in Carhart model.

\begin{tabular}{lllll}
\hline Panel A: correlations & & & \\
\hline & $R_{i t}-R_{f}$ & $R_{m t}$ & $\mathrm{SMB}_{t}$ & $\mathrm{UML}_{t}$ \\
\hline$R_{i t}-R_{f}$ & 1 & - & - & - \\
$R_{m t}$ & $0.589^{*}$ & 1 & - & - \\
$\mathrm{SMB}_{t}$ & $0.443^{*}$ & $0.485^{*}$ & 0.012 & - \\
$\mathrm{HML}_{t}$ & $0.331^{*}$ & $0.219^{*}$ & - & - \\
$\mathrm{UMD}_{t}$ & 0.183 & 0.336 & $0.441^{*}$ & -
\end{tabular}

Panel B: summary of estimated Fama/French three-factor betas

\begin{tabular}{ll}
\hline Intercept & $0.06^{*}$ \\
$M_{k t}-R_{f}$ & 0.499 \\
SMB & 0.146 \\
HML & 0.235 \\
UMD & 0.332 \\
$R^{2}$ & 0.603
\end{tabular}

Correlation is statistically significant at the 5 percent level $(P<0.05)$.

Hypotheses $2 \mathrm{a}$ and $2 \mathrm{~b}$ explore the moderating effect of firm risk on the relationship between firm performance and CEO compensation. In an environment where firm risk causes a greater uncertainty for company outcomes as well as for CEO's overall wealth, the board of directors may be inclined to award a pay premium on CEO compensation for any increase in firm performance. Statistically, this suggests an interaction between firm performance and risk. Consequently, we expect that high risk improves the magnitude of the pay-performance relationship. Eq. (4) tests Hypotheses 2a and 2b. If these expectations hold true, the coefficients on both interaction terms in Eq. (4) should yield positive signs.

$$
\begin{aligned}
\text { lnComp }_{t}= & \beta_{0}+\beta_{1} \text { Roa }_{t}+\beta_{2} \text { Return }_{t}+\beta_{3} \text { Risk }_{t}+\beta_{4} \text { InSales }_{t} \\
& +\beta_{5} \text { Age }_{t}+\beta_{6} \text { CeoOwn }_{t-1}+\beta_{7} \text { Roa }_{t} * \text { Risk }_{t} \\
& +\beta_{8} \text { Return }_{t} * \text { Risk }_{t}+\varepsilon
\end{aligned}
$$

InComp is the natural logarithm of total compensation, including salary, bonus, stock options, stock awards, and all other types of long-term payments. Roa*Risk is the interaction term, which is the product of Roa and the Risk variables. Likewise, Return*Risk is the other interaction term that is the product of Return and Risk variables. All other variables are as previously defined. To account for a potential multicollinearity problem, we mean-center Roa, Return and Risk variables that constitute the interaction terms (Aiken and West, 1991). We estimate this model along with Eqs. (2) and (3) in a system of equations via 3-sls for the previously discussed endogeneity concerns among the compensation and performance variables.

\section{Results}

\subsection{Descriptive statistics}

Beta coefficients of stocks in our sample are summarized in Table 1 below. The average beta coefficient is 1.62 for the restaurant companies included in our analyses. The minimum beta coefficient is found to be 0.20 , whereas the maximum is 4.41 . The low beta coefficient does not necessarily imply that that asset has a low level of risk, but rather it is an indication that its systematic risk component is low. The majority of the firms in our portfolio (18 out of 47 firms, 38 percent) fall between 1.50 and 2.00 systematic risk class. The grounds for the discursive correlation with market returns may be that stock(s) (i.e. Ruby Tuesday, Inc. in our sample) may have high fractions of leveraged assets and/or deviant behaviors in co-movement in prices. Hence, we see a large spread (4.21) between maximum and minimum beta values. ${ }^{2}$

Table 2 reports two panels, which are correlations between Carhart four-factor and the summary statistics of the coefficients for US restaurant industry portfolio. The correlations between SMB and HML variables with the market return are positive and statistically significant as well as with value weighted industrial stocks $\left(R_{i t}-R_{f}\right)$ in our sample. However, the correlation between SMB and HML is very weak and very close to zero. UMD and SMB correlations are found to be higher than the ones with the other factors in the model. With the high $R^{2}$ in the model, it represents a good fit among Carhart's four-factors.

Table 3 provides summary statistics for all the variables used in the analyses. For ease of economic interpretation, we report the actual dollar values of CEO total compensation (TotalComp) in addition to its log transformation used in our regression models. In our sample, average CEO total compensation is about $\$ 3.5 \mathrm{M}$. Equity compensation, on average, comprises 44 percent of the total CEO compensation for the firms included in our sample. Average return on assets (Roa) is 7 percent, whereas average stock return (Return) is 24 percent. Average firm risk for the restaurant companies included in our sample is 1.6 (risk). Mean leverage ratio is 0.22 , and mean growth rate is 0.12 . CEO age, on average, turns out to be 55 within a range of 38-73; and CEOs, on average, hold 33 percent of the total common shares outstanding in their firms.

Table 4 presents Pearson correlation coefficients among our regression variables. As expected, CEO total compensation (InTotalComp) is positively correlated with both return on assets and stock return (correlation coefficients 0.2217 and 0.1525 , respectively), which suggests that better performing firms tend to pay a higher total compensation to their CEOs. We do not observe the same correlation between performance measures and incentive compensation. The correlation between Inc_Comp and Roa and Return are both insignificant. Moreover, CEO total compensation (InTotalComp) seems to be negatively correlated with the firm risk producing a significant correlation coefficient of -0.21 . Firm size (InSales) also appears to be positively correlated with CEO total compensation - that is to indicate that larger firms reward their CEOs with a more generous compensation packages. CEO age is significantly and positively correlated with the total compensation, providing information that experience is awarded with a higher pay. Moreover, CEO's previous ownership in the company seems to

\footnotetext{
2 We winsorize the beta coefficients at 5 percent in regression estimations so as
} to reduce the large variance in the firm risk proxy. 
Table 3

Descriptive statistics.

\begin{tabular}{lccccl}
\hline Variable & Obs & Mean & Std. dev. & Min & Max \\
\hline InTotalComp & 240 & 7.7 & 0.96 & 5.80 & 10.67 \\
TotalComp & 240 & 3.536 & 4.335 & 0.329 & 43.076 \\
InCashComp & 240 & 6.66 & 1.70 & -6.91 & 9.15 \\
InEquityComp & 240 & 6.70 & 1.43 & 2.51 & 10.25 \\
Inc_Comp & 240 & 0.44 & 0.22 & 0.02 & 0.99 \\
Roa & 240 & 0.07 & 0.09 & -0.75 & 0.61 \\
Return & 240 & 0.24 & 1.71 & -0.80 & 23.75 \\
Risk & 240 & 1.62 & 0.96 & 0.20 & 4.41 \\
InSales & 240 & 6.76 & 1.14 & 4.29 & 9.75 \\
Age & 240 & 55 & 6.90 & 38 & 73 \\
CeoOwn & 240 & 32.89 & 70.65 & 0.00 & 62.14 \\
Leverage $_{\text {Growth }}$ & 240 & 0.22 & 0.21 & 0.00 & 1.32 \\
Desciptive & 240 & 0.12 & 0.17 & -0.90 & 1.21 \\
\hline
\end{tabular}

Descriptive statistics are obtained based on the observations used in Eqs. (1)-(4) TotalComp is the sum of salary, bonus, stock awards, stock options, and all other longterm pay components (tdc 1 in Compustat and is denoted in millions). InCashComp is defined as the natural logarithm of sum of salary and bonus components. InEquityComp is the natural logarithm of sum of stock options (Black and Scholes values) and restricted stock awards (grant date fair value). Inc_Comp is the ratio of EquityComp to TotalComp. Roa is the return on assets and computed as net income/total assets. Return is the annual stock return calculated as the current fiscal year end closing stock price minus previous year's closing stock price divided by the previous year's closing stock price. Risk is our measure of firm risk and is calculated using 3-factor Fama-French model for each firm and for each year of observation. InSales is the natural logarithm of sales and proxied for firm size. Age represents CEO age at current year end. CeoOwn $n_{t-1}$ is the CEO common stock ownership and calculated as the number of stocks held divided by total common shares outstanding. Leverage is defined as total long-term debt over total assets and growth is the difference between current year total sales and previous year's sales divided by previous year's sales.

be not correlated with either his/her total compensation or incentive compensation.

\subsection{Empirical results}

First hypothesis of the study predicts that as systematic risk of a company increases, it induces an adjustment in the CEO compensation. Executives facing high systematic risk for his/her firm are likely to stay away from risky/value increasing decisions that will consequently jeopardize their compensation. Thus, for a business where high systematic risk is of concern, board of directors need to tie CEO's compensation more strictly to pay components that are also likely to increase firm value. With that argument, we would expect that increased firm risk induces higher use of equity-based compensation over total compensation.

Table 5 reports the findings of 3-sls estimation of the system of equations including Eqs. (1)-(3). Panel $C$ in Table 5 exhibits the results of the compensation model. All the variables included in the compensation equation are found to be significantly affecting proportion of incentive pay paid to restaurant firms' CEOs. Two traditional performance measures, Roa and Return, are highly significant at the 5 percent level and they have positive coefficients meaning that higher firm performance leads to greater incentive pay. The positive association between performance and level of incentive pay is consistent with the findings of previous studies that documented linearly positive relationship between performance and CEO pay (Madura et al., 1996; Skalpe, 2007; Veliyath and Bishop, 1995). Further, firm size is positively related to proportion of incentive pay of CEOs' compensation in the restaurant industry. This finding is consistent with that of Core et al. (1999) study that reported larger firms paying higher total compensation to their CEOs. The positive coefficient on the firm size variable in the current study further suggests that larger firms prefer to pay higher proportion of incentive pay. CEO's previous stock ownership is also related to proportion of incentive pay. CEO's age is found to be negatively related to proportion of incentive pay. This finding is

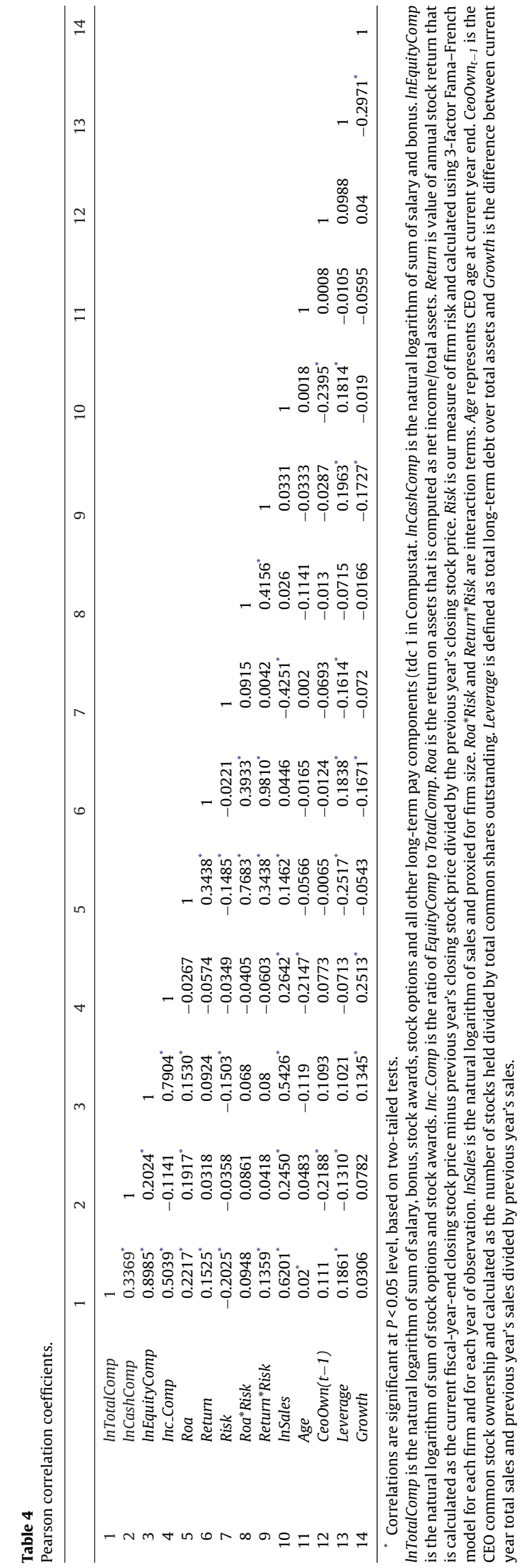


Table 5

Results of 3-sls estimation for incentive compensation hypothesis. The results of 3-sls estimation of systems of equations consisting of Eqs. (1)-(3). The hypothesized relationship between incentive compensation and firm risk tested via incentive compensation equation located in the third panel (qIncComp) of this table.

\begin{tabular}{lllll}
\hline Equation & Obs & RMSE & $R^{2}$ & $P$ \\
\hline qRoa & 240 & 0.0822762 & 0.1412 & 49.32 \\
qReturn & 240 & 1.643241 & 0.0687 & 33.66 \\
qlnComp_inc & 240 & 0.3074003 & -0.983 & 0.0001
\end{tabular}

\begin{tabular}{|c|c|c|c|c|}
\hline Variables & Coefficient & Std. error & $z$ & $P>z$ \\
\hline \multicolumn{5}{|l|}{ qRoa } \\
\hline InCashComp & -0.0004 & 0.0029 & -0.12 & 0.901 \\
\hline InSales & 0.0150 & 0.0051 & 2.96 & 0.003 \\
\hline Leverage & -0.1346 & 0.0269 & -5.01 & 0.000 \\
\hline Growth & 0.0093 & 0.0318 & 0.29 & 0.770 \\
\hline CeoOwn $(t-1)$ & 0.0001 & 0.0001 & 1.2 & 0.231 \\
\hline Intercept & 0.0073 & 0.0663 & 0.11 & 0.912 \\
\hline \multicolumn{5}{|l|}{ qReturn } \\
\hline InEquityComp & 0.3450 & 0.0859 & 4.02 & 0.000 \\
\hline InSales & -0.2248 & 0.1179 & -1.91 & 0.057 \\
\hline Leverage & 1.1012 & 0.5389 & 2.04 & 0.041 \\
\hline Growth & -0.3498 & 0.6584 & -0.53 & 0.595 \\
\hline $\mathrm{CeoOwn}(t-1)$ & -0.0020 & 0.0016 & -1.23 & 0.217 \\
\hline Intercept & -0.4182 & 1.3057 & -0.32 & 0.749 \\
\hline \multicolumn{5}{|l|}{ qInc_Comp } \\
\hline Roa & 1.5270 & 0.4764 & 3.21 & 0.001 \\
\hline Return & 0.0804 & 0.0355 & 2.26 & 0.024 \\
\hline Risk & 0.0378 & 0.0180 & 2.1 & 0.036 \\
\hline InSales & 0.0562 & 0.0157 & 3.58 & 0.000 \\
\hline Age & -0.0061 & 0.0019 & -3.17 & 0.002 \\
\hline CeoOwn $(t-1)$ & 0.0004 & 0.0002 & 1.97 & 0.049 \\
\hline Intercept & 0.0527 & 0.2279 & 0.23 & 0.817 \\
\hline
\end{tabular}

Endogenous variables: Roa Return, Inc_Comp

Exogenous variables: InCashComp, InSales, Leverage, Growth, CeoOwn(t-1)

1994.fyear 1995.fyear 1996.fyear 1997.fyear 1998.fyear 1999.fyear

2000.fyear 2001.fyear 2002.fyear 2003.fyear 2004.fyear 2005.fyear

2006.fyear lnEquityComp risk age

Inc_Comp is the ratio of equity-based compensation to total compensation. Roa is return on assets (net income divided by total assets) and Return is the annual stock return (difference between current year's closing stock price and previous year's closing stock price, divided by the previous year's closing stock price). Risk is our measure of firm risk and derived by obtaining betas from 3-factor Fama-French model using 30-day T-bill rates for risk-free rate of return. In order to reduce error variance in firm betas, betas are winsorized at 5 percent. InSales is the natural logarithm of sales. Age represents CEO age at current year end. CeoOwn(t-1) is the CEO common stock ownership in the previous year end and calculated as the number of stocks held divided by total common shares outstanding in year $t-1$.

intriguing and might have one explanation. For younger CEOs who are early in their careers in top executive positions, incentive pay may be seen as a significant motivational tool to induce them to take on risky but profitable projects. The main independent variable, firm risk, is significant at the conventional 5 percent level and has a coefficient 0.0378 . This translates to 0.0378 point increase in the proportion incentive pay for a one point increase in the firm beta. Despite the small magnitude of the coefficient, it is indicative that as the riskiness (measured in beta) of a restaurant company increases, board of directors raise the proportion of incentive pay in the CEOs' total compensation. With this result, Hypothesis 1 is confirmed.

We test Hypotheses $2 \mathrm{a}$ and $2 \mathrm{~b}$ in a similar fashion by using another system of equations including Eqs. (2)-(4). The new system of equation has a total compensation equation, not present in our tests of Hypothesis 1. Our intention is to show that the relationship between compensation and firm performance is more profound when the level of firms risk is higher for a company. In an ideal situation firms reward their executives for increased firm performance (Yoshikawa et al., 2010). Our proposition is that this reward, expressed in the form of higher total compensation, will be higher for riskier firms. We test this proposition with both accounting performance (Roa) and market performance (Return). Positive coefficients on the interaction terms between performance measures and firm risk will confirm Hypotheses $2 \mathrm{a}$ and $2 \mathrm{~b}$, leading to conclusion that when the firms are riskier, CEOs' pay level tends to be affected at a greater extent from a unit increase in the company's performance.
The main effects of Roa and Return are strongly significant in the compensation equation (Panel $C$ in Table 6). This finding is confirmative to previous research showing a positive association between pay and performance (Veliyath and Bishop, 1995; Barber et al., 2006; Dalbor et al., 2010). The firm risk variable (Risk) has a positive coefficient $(0.1634)$ implying a greater total compensation for the CEO as the level of firm risk increases for a restaurant company. This finding is significant at the 5 percent significance level $(P=0.027)$. Statistically significant positive coefficient on the risk variable is consistent with the findings of Hypothesis 1. Taken together, it could be said that riskiness of a restaurant firm increases both CEO's total compensation and proportion of incentive pay in his/her total compensation. Roa*Risk interaction term is found to be significant; however the direction of the relationship is contrary to our proposition. The negative coefficient $(-2.5605)$ can be interpreted as a decline in the total compensation of the CEO as the firm performs better for riskier firms. This finding is in complete opposition to our managerial proposition that riskier restaurant firms find it more optimal to reward their CEOs generously for increased firm performance. On the other hand, Return*Risk interaction is not significant, leading us to reject Hypothesis 2b. Opposite direction of the coefficient on Roa*Risk interaction and insignificant coefficient on Return*Risk interaction terms provide us with the conclusion that firm risk does not play a moderating role in the relationship between firm performance and CEO total pay in the US restaurant industry. This finding can imply one of following two cases: either the boards of directors of US restaurant companies do not factor firm risk into the pay-performance structure 
Table 6

Results of 3-sls estimation for moderating effect of firm risk. The results of 3-sls estimation of roa, return and total compensation equations. Panel 3 of the table shows the results of total compensation equation, where we test the moderating effect of firm risk on the compensation and performance relationship.

\begin{tabular}{lllrr}
\hline Equation & Obs & RMSE & $R^{2}$ & \multicolumn{1}{c}{$\chi^{2}$} \\
\hline qRoa & 240 & 0.0813 & 0.1617 & 47.00 \\
qReturn & 240 & 1.6908 & 0.0140 & 0.0002 \\
qComp_Int & 240 & 2.0237 & -3.4452 & 0.0000 \\
0.0000
\end{tabular}

\begin{tabular}{|c|c|c|c|c|}
\hline Variables & Coefficient & Std. error & $z$ & $P>z$ \\
\hline \multicolumn{5}{|l|}{ qRoa } \\
\hline InCashComp & 0.0054 & 0.0031 & 1.76 & 0.078 \\
\hline InSales & 0.0131 & 0.0051 & 2.59 & 0.010 \\
\hline Leverage & -0.1201 & 0.0269 & -4.46 & 0.000 \\
\hline Growth & -0.0113 & 0.0313 & -0.36 & 0.719 \\
\hline CeoOwn $(t-1)$ & 0.0001 & 0.0001 & 1.47 & 0.141 \\
\hline Intercept & -0.0832 & 0.0664 & -1.25 & 0.210 \\
\hline \multicolumn{5}{|l|}{ qReturn } \\
\hline InEquityComp & 0.4251 & 0.0621 & 6.84 & 0.000 \\
\hline InSales & -0.3031 & 0.1094 & -2.77 & 0.006 \\
\hline Leverage & 1.5899 & 0.5267 & 3.02 & 0.003 \\
\hline Growth & 0.7480 & 0.5072 & 1.47 & 0.140 \\
\hline CeoOwn $(t-1)$ & -0.0028 & 0.0016 & -1.73 & 0.084 \\
\hline Intercept & -0.6814 & 1.3052 & -0.52 & 0.602 \\
\hline \multicolumn{5}{|l|}{$q \operatorname{lnTotComp}$} \\
\hline Roa & 8.9376 & 2.2245 & 4.02 & 0.000 \\
\hline Return & 1.0309 & 0.1880 & 5.48 & 0.000 \\
\hline Roa*Risk & -2.5605 & 0.8871 & -2.89 & 0.004 \\
\hline Return*Risk & 0.3140 & 0.1874 & 1.67 & 0.094 \\
\hline Risk & 0.1634 & 0.0738 & 2.21 & 0.027 \\
\hline InSales & 0.4907 & 0.0884 & 5.55 & 0.000 \\
\hline Age & 0.0086 & 0.0066 & 1.32 & 0.187 \\
\hline CeoOwn $(t-1)$ & 0.0038 & 0.0014 & 2.79 & 0.005 \\
\hline Intercept & 2.9038 & 1.1823 & 2.46 & 0.014 \\
\hline
\end{tabular}

Endogenous variables: Roa, Return, InTotComp

Exogenous variables: InCashComp, InSales, Leverage, Growth, CeoOwn(t-1)

1994.fyear 1995.fyear 1996.fyear 1997.fyear 1998.fyear 1999.fyear 2000.fyear 2001.fyear 2002.fyear

2003.fyear 2004.fyear 2005.fyear 2006.fyear InEquityComp, Roa*Risk, Return*Risk risk age

InTotComp is the sum of cash compensation and equity-based compensation. Roa is return on assets (net income divided by total assets) and Return is the annual stock return (difference between current year's closing stock price and previous year's closing stock price, divided by the previous year's closing stock price). Risk is our measure of firm risk and derived by obtaining betas from 3-factor Fama-French model using 30-day T-bill rates for risk-free rate of return. In order to reduce error variance in firm betas, betas are winsorized at 5 percent. Roa*Risk is the interaction term between roa and risk and Return*Risk is the interaction term between stock return and risk. Roa, Return and Risk variables are mean centered (Aiken and West, 1991) to alleviate the multicollinearity. InSales is the natural logarithm of sales. Age represents CEO age at current year end. CeoOwn $(t-1)$ is the CEO common stock ownership in the previous year end and calculated as the number of stocks held divided by total common shares outstanding in year $t-1$.

of their executives, or they do that, but this mechanism does not work well in the restaurant industry. With regards to accounting performance, negative coefficient on the interaction term Roa*Risk does not comply with the traditional practice of rewarding executives for improved firm performance. It has been previously shown that restaurant firms reward their executives for increased firm performance (Madanoglu and Karadag, 2006; Guillet et al., 2012). Punishing executives for improved firm performance in a riskier restaurant firm could basically be viewed as an anomaly unless the board of directors views the riskiness of a restaurant firm as totally irrelevant to its performance. This is what we observe in the market return performance measure. The insignificant coefficient on Return*Risk variable basically implies that board of directors of restaurant companies do not view firm risk as a relevant factor in determining CEO pay based on his/her ability to produce higher return for shareholders. One of the reasons for ignoring riskiness in determining pay-performance schemes might be that board of directors might concede that restaurant firms are inherently risky and the future is relatively unpredictable. Therefore, setting a pay-performance scheme accounting for firm risk in the restaurant industry might be viewed as not cost-effective and impractical.

\section{Robustness tests}

Panel A of Table 7 reports the findings of CEO total compensation (cash compensation and equity compensation) on firm risk, performance measures, and other control variables excluding interaction terms. Our main analysis supports the proposition that as the riskiness of a restaurant company increases, its CEO will earn a higher proportion of equity-based compensation. Furthermore, the significantly positive coefficient on the risk variable (Risk) from the robustness tests suggests that CEOs' total compensation is positively related to the level of firm risk in the absence of interaction terms. This particular finding implies that board of directors take into account the level of firm risk a CEO has to bear in running a restaurant firm, and adjusts both the level and the structure of the compensation packages accordingly. Furthermore, both accounting measure (Roa) and market measure (Return) of performance are significant and positive suggesting that compensation is an increasing function of firm performance. Firm size (InSales) and CEO ownership are also significant determinants of CEO total compensation in the absence of interaction terms.

In panel B of Table 7, we use an alternative risk measure for firm risk. We use total risk as the main independent variable of our analysis and estimate Eqs. (1)-(3) via 3-sls in a similar fashion to Hypothesis 1. Despite the positive sign of the total risk variable, it is insignificant, opposite to our hypothesis that increasing firm risk raises the proportion of equity-based pay of the CEOs. This finding is inconsistent with the original risk measure beta that we use in our main analyses and implies that it is the systematic risk that matters in compensation contracting not the total risk that the firm is facing. 
Table 7

Robustness tests.

\begin{tabular}{lllrrl}
\hline \multicolumn{6}{l}{ Panel A: total compensation excluding interaction terms } \\
\hline Equation & Obs & RMSE & \multicolumn{1}{l}{$R^{2}$} & \multicolumn{1}{c}{$\chi^{2}$} & \multicolumn{1}{l}{$P$} \\
\hline qRoa & 240 & 0.081519 & 0.1569 & 48.67 & 0.0001 \\
qReturn & 240 & 1.698152 & 0.0054 & 128.05 & 0.0000 \\
qlnTotComp & 240 & 2.203752 & -4.2713 & 111.96 & 0.0000 \\
& & & & \\
Variables & Coefficient & Std. error & $z$ & $P>z$ \\
\hline qlnTotComp & & & & \\
Roa & 9.3261 & 2.6134 & 3.57 & 0.000 \\
Return & 1.1001 & 0.1988 & 5.53 & 0.000 \\
Risk & 0.1508 & 0.0700 & 2.15 & 0.031 \\
lnSales & 0.4354 & 0.0902 & 4.83 & 0.000 \\
Age & 0.0158 & 0.0063 & 2.51 & 0.012 \\
CeoOwn $(t-1)$ & 0.0034 & 0.0014 & 2.46 & 0.014
\end{tabular}

Panel B: total risk as a measure of firm risk to test for Hypothesis 1

\begin{tabular}{lllrll}
\hline Equation & Obs & RMSE & \multicolumn{1}{l}{$R^{2}$} & $\chi^{2}$ & $P$ \\
\hline qRoa & 240 & 0.0820473 & 0.1459 & 49.66 & 0.0001 \\
qReturn & 240 & 1.636413 & 0.0764 & 31.1 & 0.0281 \\
qComp_inc & 240 & 0.2895792 & -0.7597 & 56.05 & 0.0000
\end{tabular}

\begin{tabular}{lrccc} 
Variables & Coefficient & Std. error & $z$ & $P>z$ \\
\hline qInc_Comp & & & & \\
Roa & 1.3657 & 0.4711 & 2.9 & 0.004 \\
Return & 0.0696 & 0.0353 & 1.97 & 0.049 \\
Risk & 0.0172 & 0.0130 & 1.32 & 0.187 \\
InSales & 0.0528 & 0.0157 & 3.36 & 0.001 \\
Age & -0.0064 & 0.0019 & -3.3 & 0.001 \\
CeoOwn(t-1) & 0.0004 & 0.0002 & 1.86 & 0.062 \\
Intercept & 0.1173 & 0.2224 & 0.53 & 0.598
\end{tabular}

Panel C: total risk as a measure of firm risk to test for Hypotheses $2 \mathrm{a}$ and $2 \mathrm{~b}$

\begin{tabular}{lccccc}
\hline Equation & Obs & RMSE & $R^{2}$ & \multicolumn{1}{l}{$\chi^{2}$} & $P$ \\
\hline qRoa & 240 & 0.0806166 & 0.1755 & 50.6 & 0.0001 \\
qReturn & 240 & 1.616194 & 0.0991 & 31.04 & 0.0284 \\
qlnComp_int & 240 & 0.6505914 & 0.5406 & 295.47 & 0.0000 \\
& & & & \\
Variables & Coefficient & Std. error & $z$ & $P>z$ \\
\hline qlnTotComp & & & & \\
Roa & 1.0905 & 0.6349 & 1.72 & 0.086 \\
Return & 0.0927 & 0.0389 & 2.38 & 0.017 \\
Roa*Risk & -0.3683 & 0.2398 & -1.54 & 0.124 \\
Return*Risk & -0.0149 & 0.0573 & -0.26 & 0.794 \\
Risk & 0.0679 & 0.0380 & 1.79 & 0.074 \\
InSales & 0.5844 & 0.0453 & 12.9 & 0.000 \\
Age & -0.0002 & 0.0062 & -0.03 & 0.979 \\
CeoOwn(t-1) & 0.0039 & 0.0006 & 6.08 & 0.000 \\
Intercept & 2.7171 & 0.6099 & 4.45 & 0.000 \\
\hline
\end{tabular}

InTotComp is the sum of cash compensation and equity-based compensation. Roa is return on assets (net income divided by total assets) and Return is the annual stock return (difference between current year's closing stock price and previous year's closing stock price, divided by the previous year's closing stock price). Risk is our measure of firm risk and derived by obtaining betas from 3-factor Fama-French model using 30-day T-bill rates for risk-free rate of return. Roa*Risk is the interaction term between roa and risk and Return*Risk is the interaction term between stock return and risk. Roa, Return and Risk variables are mean centered (Aiken and West, 1991 ) to alleviate the multicollinearity. InSales is the natural logarithm of sales. Age represents CEO age at current year end. CeoOwn $(t-1)$ is the CEO common stock ownership in the previous year end and calculated as the number of stocks held divided by total common shares outstanding in year $t-1$.

Panel $\mathrm{C}$ of Table 7 illustrates findings for Hypotheses 2a and $2 \mathrm{~b}$ when we use total risk as the measure of firm risk. None of the interaction terms in the Panel $\mathrm{C}$ of Table 7 are significant implying total risk does not moderate the relationship between pay and performance for restaurant firms' CEOs. This finding is consistent with the main findings when the firm beta is utilized as the proxy of risk (see Table 6).

\section{Concluding remarks}

Taking our motivation from the risk and compensation literature, we investigated whether firm risk, operationalized as firm's systematic risk, affects CEO compensation contracting in the US restaurant industry. Using a similar logic to that of Sanders and Carpenter (1998), we hypothesized that risk is a source of organizational complexity and, therefore, increases both the information-processing demands placed on top management teams and difficulty of executive monitoring by boards. Thus, board of directors have to take initiatives to handle the complexity stemming from the firm risk companies encounter, and structure compensation contracts that are optimally designed to induce executives to make optimum business decisions.

In our first set of tests, we examined the structural change in the CEO's compensation with regard to level of firm risk he/she has to deal with as the top executive of the company. We specifically argued that firms with higher systematic risk would be likely to allocate a higher ratio of equity-based compensation to total compensation as an incentive device as suggested by Sanders and Carpenter (1998). Our findings suggest that board of directors of US restaurant companies use equity-based compensation as an incentive to motivate their CEOs due to increasing firm risk. This finding further suggests that board of directors of restaurant companies differentiates between a high-risk profile and low-risk profile company when structuring CEO pay package. This finding is in accord with the expectation that in the presence of high firm risk, executives would have regarded a higher proportion of equity-based compensation advantageous to their own wealth. Consequently, they would strive to perform better to improve the financial performance of the firm, and so increase their own wealth, which is tied to performance of the firm. Especially in a high-risk industry such as the restaurant industry, where the average compensation for senior executives falls behind those of incumbents in larger industries, this pay mechanism would motivate upper level managers to perform higher. Despite the restaurant industry's overall strength in the US economy, individual restaurant companies are considerably smaller enterprises compared to larger services and manufacturing firms. Smaller sizes could intuitively imply that there are not yet advanced and well-accepted compensation mechanisms in the restaurant industry. However, the observed relationship between firm risk and proportion of equity-based compensation and also the level of compensation as evidenced in the robustness analyses is promising for further applications of more advanced pay mechanisms in the restaurant industry.

Previous research has shown that boards reward their executives with large pay-checks for improved firm performance (Jensen and Murphy, 1990; Mehran, 1995; McConnell and Servaes, 1990). This has been regarded as a significant motivational tool for compensation committees to encourage manager to act in the best interest of owners (Veliyath and Bishop, 1995). With the increasing firm risk for a given company, executive may be less inclined to take on risky projects that are expected to increase shareholder wealth. Besides, firm risk increases operational and financial complexity for managers to make optimum business decisions; and achieving organizational and financial benchmarks should be considerably more significant for riskier firms. With these arguments, we anticipated that board of directors of the firms that are exposed to higher firm risk assign significantly higher pay premium on the CEO's compensation for the increased firm performance relative to less risky firms. Our findings do not provide direct evidence for this proposition when we measure performance both as stock returns and accounting returns. From a managerial point of view, a manager/executive would be rewarded for his/her competence to effectively manage high firm risk, and a proper reward system on his/her compensation would increase his/her motivation for 
improved future performance. Lack of such compensation practices in the restaurant industry must be of great concern for executives, compensation committees, and board of directors.

Consistent with previous compensation studies, we found firm performance and size to be positively associated with both level and structure of CEO compensation. Our results also indicate that CEO previous stock ownership is positively related to his/her overall compensation and percentage of equity-based compensation

\section{Limitations and future research}

We acknowledge that our results are applicable only to the firms similar to the restaurant companies included in our sample. Yet, firms that operate in similar settings can benefit from our findings for CEO compensation contracting. We must also admit that we work with a considerably smaller data set compared to studies in mainstream accounting/finance literature. However, each of our regressions has approximately 240 firm-year observations, which we believe is enough to obtain reliable test results. Furthermore, we suggest that a larger data set would produce more robust statistical analyses, yet we maintain that this data set includes all firm years available from ExecuComp database. We also note that our results pertinent to firm risk are valid to the extent that we correctly specify the firm risk. Econometrically, we use a 3-sls regression approach to estimate our regression equations. For further investigations, researchers can look into more advanced econometric techniques to handle the endogeneity problem occurring between compensation and performance. We propose that further research may investigate the association between risk and different components of compensation. A further extension in this line of research would be to find hospitality industry-specific factors that can affect the relationship between compensation and firm risk. Veliyath et al. (1994) posit that because managerial operations are executed according to firm strategy, an optimal incentive contract for executives is also likely to depend on firm strategy. Hence, our results may be of interest to policy makers for the firms in a way that together with a sufficient bundle of firm's strategy, firm's compensation policies can be better aligned. Finally, another area to be explored in the analysis of the design of executive compensation and risk might be the influence of other forms of risk, such as idiosyncratic, financial, business, and actual compensation risk, on CEO compensation in different segments of the hospitality industry such as airline and retail sectors. Also, theorizing how asset contraction policies such as stock splits, spinoffs, and dividend policies may affect prospective CEO compensation contracts would be recommended for further research.

\section{References}

Aggarwal, R.K., Samwick, A.A., 1999. The other side of the trade-off: the impact on risk on executive compensation. Journal of Political Economy 107 (1), 65-105.

Aiken, L.S., West, S.G., 1991. Multiple Regression: Testing and Interpreting Interactions. Sage Publications, Newbury Park, CA.

Anderson, M.C., Banker, R.D., Ravindran, S., 2000. Executive compensation in information technology industry. Management Science 46, 1411-1438.

Attaway, M.C., 2000. A study of the relationship between company performance and CEO compensation. American Business Review 18 (1), 77.

Balsam, S., Fernando, D.G., Tripathy, A., 2011. The impact of firm strategy on performance measures used in executive compensation. Journal of Business Research 64 (2), 187-193.

Barber, N., Ghiselli, R., Deale, C., 2006. Assessing the relationship of CEO compensation and company financial performance in the restaurant segment of the hospitality industry. Journal of Food Service Business Research 9 (4), 65-82.

Belsley, D.A., 1988. Tow- or three-stage least squares? Computer Science in Economics and Management 1 (1), 21-30.

Bloom, M., Milkovich, G.T., 1998. Relationships among risk, incentive pay, and organizational performance. Academy of Management Journal 41 (3), 283-297.

Boyd, B.K., 1994. Board control and CEO compensation. Strategic Management Journal 15 (5), 335-344
Canarella, G., Nourayi, M.M., 2008. Executive compensation and firm performance: adjustment dynamics, non-linearity, and asymmetry. Managerial and Decision Economics 29, 293-315.

Carhart, M., 1997. On persistence of mutual fund performance. Journal of Finance $52,57-82$.

Chhaochharia, V., Grinstein, Y., 2009. CEO compensation and board structure. Journal of Finance 64, 231-261.

Conyon, M.J., Peck, S.I., Sadler, G.V., 2001. Corporate tournaments and executive compensation. Strategic Management Journal 22 (8), 805-815.

Cooley, P.L., 1979. Managerial pay and financial performance of small business. Journal of Business Research 7 (3), 267-276.

Core, J., Holthausen, R.W., Larcker, D.F., 1999. Corporate governance, chief executive officer compensation, and firm performance. Journal of Financial Economics 51 371-406.

Coughlan, A., Schmidt, R., 1985. Executive compensation, management turnover and firm performance. Journal of Accounting and Economics 7, 43-66.

Crumley, C.R., 2008. A study of relationship between firm performance and CEO compensation in the U.S. commercial banking industry. Journal of Applied Management and Entrepreneurship 13 (2), 26-46.

Dalbor, M., Oak, S., Rowe, T., 2010. How closely is CEO compensation tied to performance? An examination of the U.S. restaurant industry. Journal of Hospitality Financial Management 18 (2), 1-13.

De Noble, A.F., Olsen, M.D., 1986. The food service industry environment: market volatility analysis. FIU Hospitality Review 4 (2), 89-100.

Duru, A.I., Iyengar, R.J., 1999. Linking CEO pay to firm performance: empirical evidence from the electric utility industry. Managerial Finance 25 (9), 21-34.

Fama, F.E., French, R.K., 1992. The cross-section of expected stock returns. Journal of Finance 47 (2), 427-465.

Fama, F.E., French, R.K., 1993. Common risk factors in the returns on stocks and bonds. Journal of Financial Economics 33 (1), 3-56.

Finkelstein, S., Hambrick, D.C., 1988. Chief executive compensation: a synthesis and reconciliation. Strategic Management Journal 9 (6), 543-558.

Firth, M., Fung, P.M.Y., Oliver, M.R., 2007. How ownership and corporate governance influence chief executive pay in China's listed firms. Journal of Business Research 60, 776-785.

Florackis, C., Kostakis, A., Ozkan, A., 2009. Managerial ownership and performance. Journal of Business Research 62 (12), 1350-1357.

Garen, J.E., 1994. Executive compensation and principal-agent theory. Journal of Political Economy 102, 1175-1199.

Glassman, C.A., Rhoades, S.A., 1980. Owner vs. manager control effects on bank performance. Review of Economics and Statistics 27, 263-270.

Gomez-Mejia, L.R., Tosi, H., Hinkin, T., 1987. Managerial control, performance, and executive compensation. Academy of Management Journal 30 (1), 51-70.

Gray, R.S., Canella, A.A., 1997. The role of risk in executive compensation. Journal of Management 23 (4), 517-540.

Guillet, B.D., Kucukusta, D., Xiao, Q., 2012. An examination of executive compensation in the restaurant industry. International Journal of Hospitality Management 31, 86-95.

Haggard, D.L., Haggard, K.S., 2008. Executive compensation: does industry risk matter? International Journal of Organization Theory and Behavior 11 (4) $451-470$

Huo, Y.H., Kwansa, F., 1994. Effect of operating and financial leverage on firm's risk Journal of the International Academy of Hospitality Research 8 (3), 1-10.

Iyengar, R.J., Zampelli, E.M., 2008. Auditor independence, executive pay and firm performance. Accounting and Finance 48, 259-278.

Jang, S.G., Park, K., 2011. Hospitality finance research during recent two decades:subjects, methodologies, and citations. International Journal of Contemporary Hospitality Management 23 (4), 479-497.

Jensen, M.C., Meckling, W.H., 1976. Theory of the firm: managerial behavior, agency costs and ownership structure. Journal of Financial Economics 3, 305-360.

Jensen, M.C., Murphy, K.J., 1990. Performance pay and top management incentives. Journal of Political Economy 98 (2), 225-265.

Jurkus, F.A., Park, C.J., Woodard, S.L., 2011. Women in top management and agency costs. Journal of Business Research 64, 180-186.

Ke, B., Petroni, K., Safieddine, A., 1999. Ownership concentration and sensitivity of executive pay to accounting performance measures: evidence from publicly and privately-held insurance companies. Journal of Accounting and Economics, 185-209.

Khan, R., Dharwadkar, R., Brandes, P., 2005. Institutional Ownership and CEO compensation: a longitudinal examination. Journal of Business Research 58 $1078-1088$.

Kim, H., Gu, Z., 2005. A preliminary examination of determinants of CEO cash compensation in the U.S. restaurant industry from an agency theory perspective. Journal of Hospitality \& Tourism Research 29 (3), 341-355.

Kim, W.G., 2009. Risk adjusted performance of three restaurant segments in the USA Tourism Economics 15 (1), 139-152.

Kothari, S.P., Shanken, J., Sloan, R.G., 1995. Another look at the cross-section of expected stock returns. Journal of Finance 50 (1), 185-224

Kroll, M., Simmons, S.A., Wright, P., 1990. Determinants of chief executive officer compensation following major acquisitions. Journal of Business Research 20 349-366.

Madanoglu, M., Karadag, E., 2006. CEO pay for performance sensitivity in the restaurant industry: what makes it move? Journal of Foodservice Business Research 11. (2).

Madura, J., Martin, A.D., Jessel, K.A., 1996. Determinants of CEO compensation in small publicly-traded businesses. American Business Review 14, 80-88. 
Mandelker, N.G., Rhee, G., 2009. The impact of the degrees of operating and financial leverage on systematic risk of common stock. Journal of Financial and Quantitative Analysis 19 (1), 45-57.

McConnell, J.J., Servaes, H., 1990. Additional evidence on equity ownership and corporate value. Journal of Financial Economics 27 (2), 595-612.

Mehran, H., 1995. Executive compensation structure, ownership, and firm performance. Journal of Financial Economics 38, 163-184.

Miller, S.J., Wiseman, R.M., Gomez-Mejia, R.L., 2002. The fit between CEO compensation design and firm risk. Academy of Management Journal 45 (4), 745-756.

Murphy, K., 1985. Corporate performance and managerial remuneration. Journal of Accounting and Economics 7, 11-42.

Murphy, K.J., 2000. Performance standards in incentive contracts. Journal of Accounting and Economics 30, 245-278.

Parsa, H.G., Self, J.T., Njite, D., King, T., 2005. Why restaurants fail. Cornell Hospitality Quarterly 46 (3), 304-323.

Risk Center, 2009. Industry Risk - 2009 U.S. Restaurant Outlook, Credit Risk Escalates as Challenges Persist, Retrieved from http://www.riskcenter.com/ story.php?id=17411 (accessed 18.04.11)

Sanders, G., Carpenter, M.A., 1998. Internationalization and firm governance: the roles of CEO compensation, top team composition, and board structure. Academy of Management Journal 41 (2), 158-178.

Shavell, S., 1979. Risk sharing and incentives in the principal and agent relationship. Bell Journal of Economics 10, 55-73.

Skalpe, O., 2007. The CEO gender pay gap in the tourism industry - evidence from Norway. Tourism Management 28, 845-853.
Switzer, L.N., Tang, M., 2009. The impact of corporate governance on the performance of U.S. small-cap firms. International Journal of Business 14 (4), 341-355.

Tosi, H.L., Werner, S., Katz, J.P., Gomez-Meija, L.R., 2000. How much does performance matter? A meta analysis of CEO pay studies. Journal of Management 26 (2), 301-339.

Veliyath, R., Bishop, J.W., 1995. Relationship between CEO compensation and firm performance: empirical evidence of labor market norms. International Journal of Organizational Analysis 3 (3), 268-283.

Veliyath, R., Ferris, S., Ramaswamy, K., 1994. Business strategy and top management compensation: the mediating effects of employment risk, firm performance and size. Journal of Business Research 30 (2), 149-159.

Wall Street Journal, 2011, April 15. CBS CEO Moonves 2010 Compensation Valued at $\$ 57.7 \mathrm{M}$, Retrieved from http://online.wsj.com/article/BT-CO20110415-713114.html?mod=wsj_qt_latest_wsj (accessed 17.04.11).

Walsh, J.P., Seward, J.K., 1990. On the efficiency of internal and external corporate control mechanisms. Academy of Management Review 15, 421-458.

Wen, M., Chen, C.R., 2008. The relationship between executives' option-based compensation and risk taking in the property/liability insurance industry. Journal of Insurance Regulation 26 (3), 85-109.

Wu, J., Tu, R., 2007. CEO stock option pay and R\&D spending: a behavioral agency explanation. Journal of Business Research 60, 482-492.

Yoshikawa, T., Rasheed, A.A., Del Brio, E.B., 2010. The impact of firm strategy and foreign ownership on executive bonus in Japanese firms. Journal of Business Research 63, 1254-1260. 